\title{
Academic Service Quality Survey in Higher Education
}

\author{
Cucun Sunaengsih*, Aan Komariah, Dedy Achmad \\ Kurniady, Muthahharah Thahir \\ Educational Administration Department, School of \\ Postgraduate Studies \\ Universitas Pendidikan Indonesia \\ Bandung, Indonesia \\ *cucunsunaengsih@upi.edu
}

\author{
Badrud Tamam \\ Educational Management \\ Postgraduate School \\ Wiralodra University \\ Indramayu, Indonesia
}

\begin{abstract}
This research aims to identify the implementation of academic service quality in Higher Education in Indonesia. The academic service is a core product of the Higher Education so positively perceived academic service quality will also lead to positive image of the Higher Education. However, inconsistency of academic service process gives negative effects on academic service image which is offered by the Higher Education. Based on this issue, the researchers take a descriptive research by a survey method to the students in Higher Education in Indonesia. Results of the research that are seen from reliability, responsiveness, assurance, empathy and tangible dimensions show various results. The implication of this research is that Higher Education can have ability to improve its academic service through more consistent, flexible and proper academic service paths to the students' needs.
\end{abstract}

Keywords—academic service, higher education, quality

\section{INTRODUCTION}

Higher Education as one of the education institutions is required to give qualified education service so that it can be accountable and qualified [1-3],. Higher Education as a service industry must start to think the importance of customer service in a more mature manner because there is an increasing awareness that customer service and satisfaction serve as vital aspects in maintaining business and winning the competition. Student satisfaction is assumed to be determined by service quality related to the academic [4,5]. Academic service has greater portion in education service. Academic service is a service greatly related directly to students, so Higher Education in giving academic service must try to understand and meet students' needs and ultimately on students' perception [4,6]. A qualified academic service will lead to students' satisfaction. Student satisfaction is shown by student loyalty in Higher Education and students will tell the satisfied academic service to others [7,8]. Academic service quality in Higher Education is determined five main dimensions, namely reliability, responsiveness, empathy, tangibility, and assurance [9].
Quality is a keep moving and dynamic thing, if it is moving forward then it is said to be quality improvement, if it is moving backward then it is said to be quality decrease [10]. Quality can be defined as superiority or excellence namely exceeding the applied genera standard. A thing can be said to be qualified if there is a compatibility between requirements owned by the desired objects or service by the people who will. Service quality is the extent to which the service given by a company is based on customer needs and expectation [11]. Service quality is the extent of differences of reality and customer expectation that they accept. Academic service quality is the value given by the customer on the give ac customer academic service based on the customer expectation. The customers in this case are the students who will state whether the academic is qualified based on their specification or not. Academic service quality in this research is the value given on the level of good academic service based on student expectation [12].

Related to the academic service reality in the field, there are still many complains given by students. The complains by the students concerning the academic service include: (1) the number of equipment and facility of practice tools in the laboratory which is not yet met based on the number of students for example less number of computer than the number of students doing the practice in the computer laboratory, incomplete equipment appliances in the laboratory (2) the absence of library facility in each department (3)academic service in administration section which cannot be done in a fast, responsive and appropriate manner (4) recommendations of improvement and maintenance for the facility and infrastructure as well as equipment are yet applied, for example in typing laboratory, there are still many damaged typing tools (5)less relevant curriculum and course materials to the business world (6) the absence of research between lecturers and students [13-15]. From these clear illustrations, it often faces problems related to academic service quality, but in the illustration, there are no any main dimensions of Higher Education academic service quality such as reliability, responsiveness, empathy, tangibility, and assurance. Also, this 
research survey is yet not conducted on primary school teacher education study program. Thus, the researchers are interested at taking a survey on academic service quality for each indicator of academic service quality related to reliability, responsiveness, empathy, tangibility, and assurance so it can determine how the description of academic service quality of primary school teacher education study program is.

\section{RESEARCH METHODOLOGY}

The method used in this research is a quantitative method with literature study and survey. With this method, it is expected that the researchers will be able to obtain an overview of the academic service quality. In the data collection, the researchers used a questionnaire with the students in the primary school teacher education study program as the object research since they are considered as one of the parties who directly experience the academic services provided by the higher education. After conducting probability sampling method with simple random sampling, the number of participating students was 234 people. Meanwhile, literature study was carried out by examining various journals and other relevant sources. The data obtained were then analyzed using frequency analysis and histograms so that it can draw the percentages for each indicator in each dimension of the academic service quality.

\section{RESULTS AND DISCUSSION}

Academic service quality is the value given by customers based on their expectation. Academic service quality in Higher Education is determined by five main dimensions, namely reliability, responsiveness, empathy, tangibility, and assurance. Based on these academic service quality, results of the survey show the illustration of academic service quality in the primary school teacher education study program is as the following:

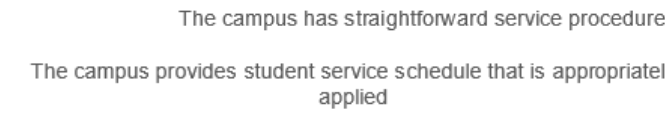

The campus provides proper academic administration services

The campus provides fast academic administration services

The campus has a proper procedure for receiving student complaints

The campus has a fast procedure for receiving student complaints

The campus has a proper procedure for student needs

The campus has fast procedures for student needs

Fig. 2. Reliability dimension.

From the picture above, it can be seen that the reliability dimension consisting of the indicators the campus has fast procedures for student needs; the campus has a proper procedure for student needs; the campus has a fast procedure for receiving

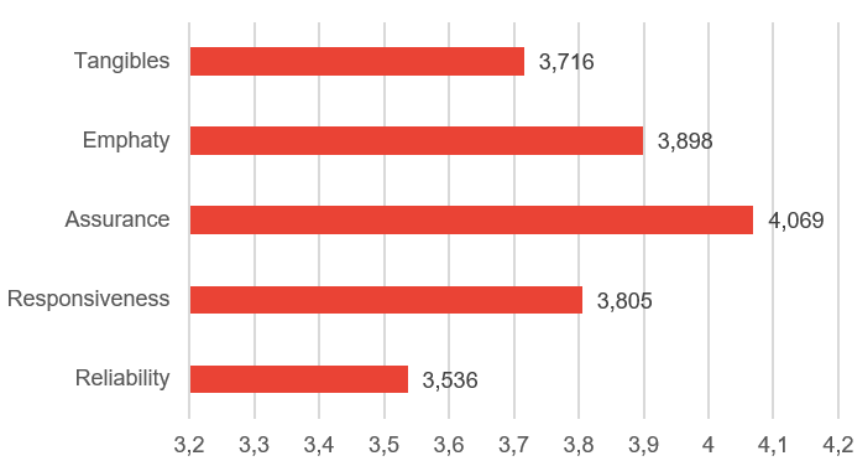

Fig. 1. Academic service quality.

From the picture above, the dimension of academic quality with the highest level of implementation according to the students' perspective is the assurance dimension with a score of 4.069 which is then followed by the empathy dimension with a score of 3.898, responsiveness with a score of 3.805 , tangibles with a score of 3.715 and finally, reliability with a score of 3.536. . From the acquisition of the highest score, it shows that the higher education has been able to guarantee the students' trust, meaning that the ability given by the higher education to serve the students' needs has been as promised and on time. However, from the acquisition of the reliability score which shows the lowest score, it shows that the reliability of the higher education institution in providing services must be improved. It still must improve the red tape service procedures and also to meet students' needs and receiving student complaints. For more details, the following is an illustration of the quality of academic services for each indicator in each dimension:

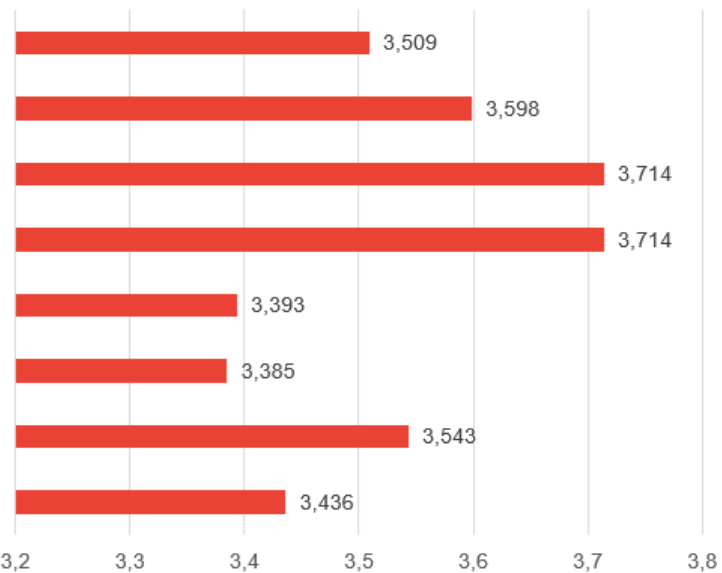

student complaints; the campus has a proper procedure for receiving student complaints; the campus provides fast academic administration services; the campus provides proper academic administration services; the campus provides student service 
schedule that is appropriately applied; the campus has straightforward service procedures; show different results. Out of all the existing indicators, the campus indicators of providing a fast and proper academic administration services are the indicators with the highest score compared to other indicators. Meanwhile, the campus indicator of having a fast procedure for receiving student complaints is the indicator with the lowest score. From these findings, it can be seen that students still feel less about the quality of fast academic services. Reliability is the ability to provide services as promised, reliable and accurate, consistent and service conformity [9]. Thus, in Higher Education, straightforward academic services between students, lecturers and administration department is the core of the implementation of the reliability dimension. In this study, apart from reliability, the following picture is the responsiveness dimension:

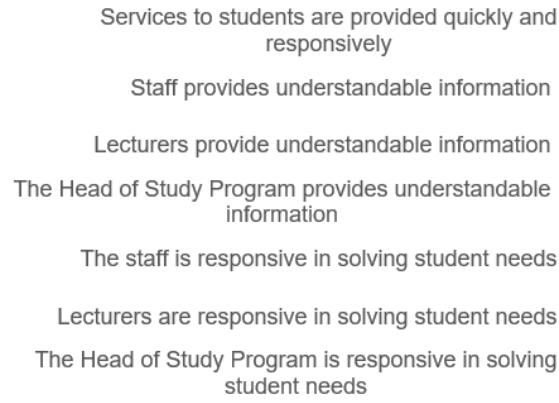

Fig. 3. Responsiveness dimension

Responsiveness dimension consists of indicators, namely the Head of Study Program is responsive in solving student needs; lecturers are responsive in solving student needs; The staff is responsive in solving student needs; The Head of Study Program provides understandable information; Lecturers provide understandable information; Staff provides understandable information

Services to students are provided quickly and responsively; that the Head of Study Program is responsive in solving student needs, Lecturers are responsive in solving student needs, Staff is responsive in solving student needs, Head of Study Program provides information that is easy to understand, Lecturers provide information that is easy to understand, Staff provides information that is easy to understand and Services to students are provided

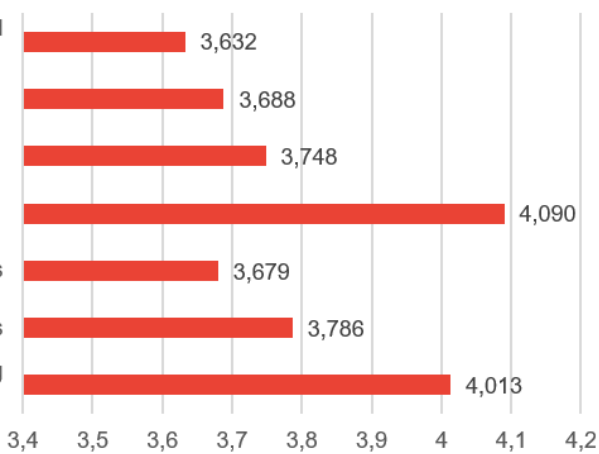

quickly and responsively. From the picture above, it is known that the head of the study program provides understandable information which is the indicator with the highest score acquisition, while the indicator of providing fast service o the students is the indicator with the lowest score. Responsiveness in this study is defined as the willingness of the head of study program, lecturers or academic staff to help the customers, namely students, in providing fast services as well as hearing and resolving their arising complaints. The point is that higher education institution tries to respond to students' complaints and needs. With a fast response, certainly, it will have an impact on the quality of services provided by the higher education to the students. The following is a figure showing the assurance dimension based on the results of a survey on the students:

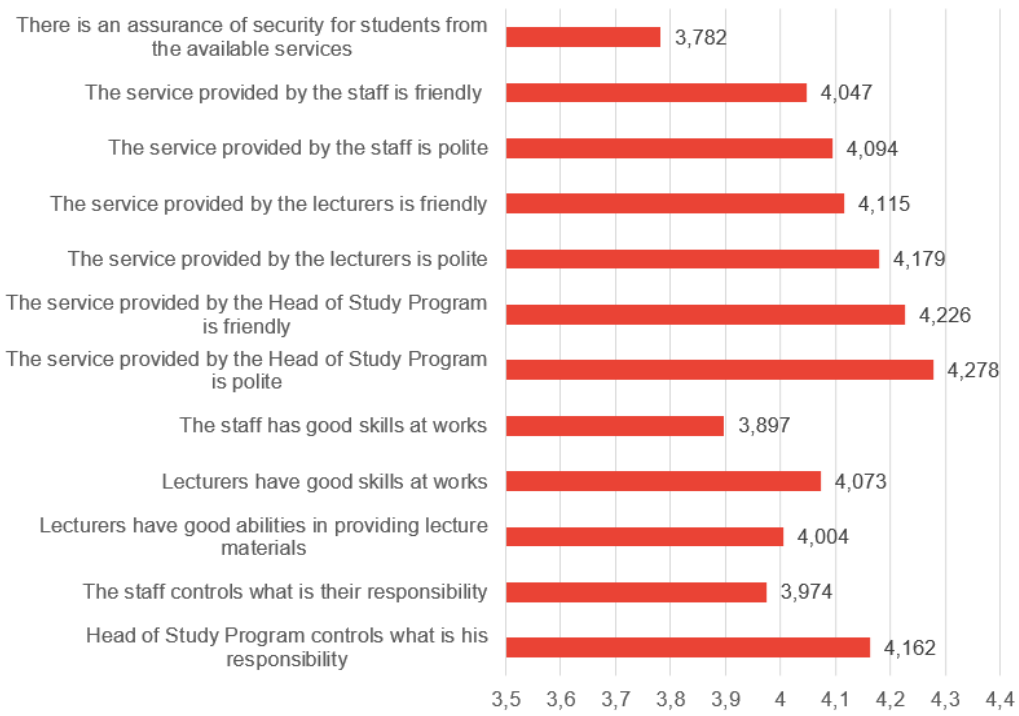

Fig. 4. Assurance dimension. 
The Assurance Dimension consists of indicators namely Head of Study Program controls what is his responsibility. The staff controls what is their responsibility; Lecturers have good abilities in providing lecture materials; Lecturers have good skills at works; The staff has good skills at works; The service provided by the Head of Study Program is polite; The service provided by the Head of Study Program is friendly; The service provided by the lecturers is polite; The service provided by the lecturers is friendly; The service provided by the staff is polite; The service provided by the staff is friendly; There is an assurance of security for students from the available services. The service provided by the head of study program is polite, it is the indicator with the highest score, while there is an assurance of security for students from the available services is the indicator with the lowest score. The high and low of each indicator is determined by the level of the quality of services offered by the Higher Education Institutions. Assurance is the ability of employees to generate confidence and trust as promise given to the consumers [9]. This dimension requires the head of study program, lecturers and staff to keep their promises in providing services to students. With the fulfillment of promises accompanied by high abilities in carrying out tasks, it is believed that students will believe that the academic service offered is in a high level of quality academic service.

In addition to reliability, responsiveness, and assurance, the following is a description of the results of a survey on the students for the empathy dimension:

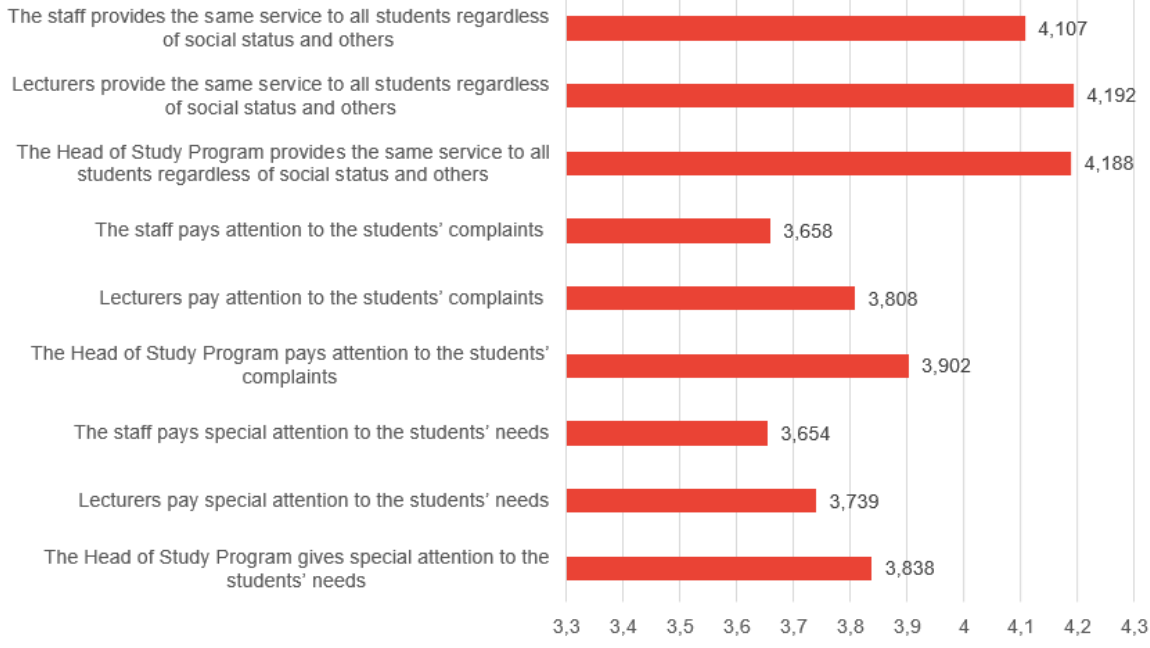

Fig. 5. Empathy dimension.

The Empathy Dimension is one of the dimensions having the most influences on the level of quality of academic services. Empathy is the willingness of employees to care more about giving personal attention to customers [9]. For example, placing yourself as a customer, if a customer complaints, there must be a solution by showing a genuine sense of care. The Emphaty Dimension consisting the indicators namely The Head of Study Program gives special attention to the students' needs; Lecturers pay special attention to the students' needs; The staff pays special attention to the students' needs; The Head of Study Program pays attention to the students' complaints; Lecturers pay attention to the students' complaints; The staff pays attention to the students' complaints; The Head of Study Program provides the same service to all students regardless of social status and others; Lecturers provide the same service to all students regardless of social status and others; The staff provides the same service to all students regardless of social status and others. From the picture above, it can be seen that the indicator of that the lecturers provide the same service to all students regardless of social status and others is the indicator with the highest score while the indicator of the staff gives special attention to student needs is the indicator of the empathy dimension with the lowest score. It cannot be denied that special attention to the students' needs cannot be given maximally due to the obligation to complete other tasks that must be fulfilled by the head of study program, lecturers and staff. However, it must be understood that any tasks that must be completed by the Head of Study Program, lecturers and staff, in essence, must lead to improve the quality of academic services for students as well.

The final survey result of the quality of academic services is the tangible dimension. This dimension shows different results for each indicator, it can be seen in the following figure:

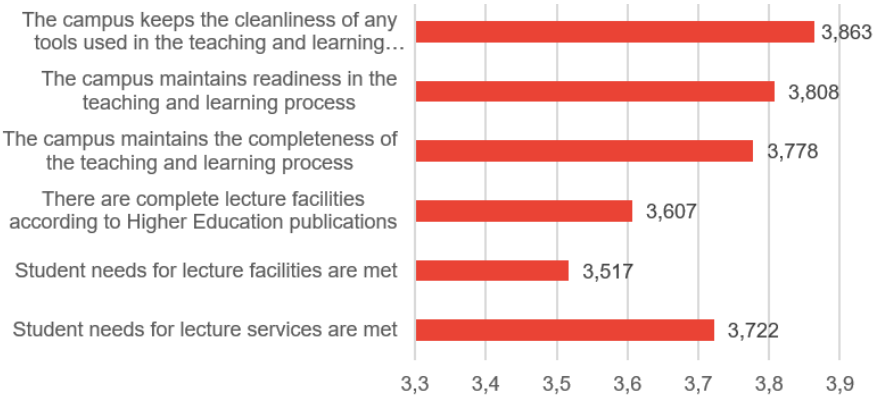

Fig. 6. Tangible dimension. 
The Tangible dimension consists the indicators namely of student needs for lecturing services being met, student needs for lecture facilities are met, complete lecture facilities in accordance with Higher Education publications, the campus maintains the completeness of the teaching and learning process, the campus maintains readiness in the teaching and learning process and the campus maintains the cleanliness of the equipment used in the teaching and learning process. From the picture above, it can be seen that the indicator of the campus maintains the cleanliness of any tools used in the teaching and learning process is the highest indicator while the indicator of the students' need for lecture facilities is met is the lowest indicator. Tangible is the appearance of physical facilities, equipment, and various communication materials [9]. In an environment of Higher Education, physical facilities can be seen from the cleanliness, tidiness, and comfort of the study rooms. It is also about the room arrangement both interior and exterior; Adequate learning equipment, readiness for use such as presentation facilities, multimedia communication tools, and others. All of these indicators, if they are implemented properly, will greatly give impacts on students' perceptions on the quality of the offered academic by the higher education institution.

The quality of academic services is very important to be noticed and improved in Higher Education [16]. Service quality is always dynamic and developing in order to meet customer expectations [9]. Customer expectations also grow to meet market demands and developments in the world of work. Meanwhile, the influence of the quality of academic service variable shows greater effects than the bureaucracy on the quality of Higher Education, so it is expected that the quality of academic services will always be continuously improved [7]. The final goal of academic service is the quality of higher education [17,18]. The quality of academic services is one of the dominant variables giving effects on the quality of higher education, in addition to other variables such as: cost or price, product, situational factors, personal factors, and other aspects $[19,20]$, so good academic service quality by the Higher Education will give effects on the image of the Higher Education itself [1]. The main customers of Higher institution are students, so the quality of academic services will greatly give effects on student satisfaction as the main customers [2123]. Academic service quality serves as the most important thing to be considered and improved in the Higher Education.

\section{CONCLUSION}

Academic service quality is a comparison of the academic service perceived by the customers of stakeholders with the academic service quality expected by the customers or stakeholders. If the academic service quality is perceived to be the same or exceeding the expected service quality, then the service is said to be qualified. The main dimensions of university academic service quality consisting of reliability, responsiveness, empathy, tangibility, and assurance based on the survey show different results but each dimension is still in good category. The implication of this research is that Higher
Education can have ability to improve its academic service through more consistent, flexible and proper academic service paths to the students' needs.

\section{ACKNOWLEDGMENT}

This research is a preliminary research conducted in completing a doctoral study in school education administration study program, Post Graduate of Universitas Pendidikan Indonesia. Thus, this research is fully supported by the education administration study program, primary school teacher education study program and early childhood education study program as the place for this research.

\section{REFERENCES}

[1] H.F.A. Hasan, A. Ilias, R.A. Rahman, M.Z.A. Razak, Service Quality and Student Satisfaction: A Case Study at Private Higher Education Institutions, vol. 1, International Business Research, 2009.

[2] M.J. Hossain, S.M.Z. Ahmed, An Investigation of Service Expectations: Developing and Validating an Alternative Scale for Service Quality Assessment in Academic Libraries, 2014.

[3] M.J. Hossain, "Determining the Key Dimensions for Evaluating Service Quality and Satisfaction in Academic Libraries", vol. 48, International Information and Library Review, pp. 176-189. 2016.

[4] J. Atkinson, "Academic Libraries and Quality: An Analysis and Evaluation Framework", vol. 23, New Review of Academic Librarianship, pp. 421-441. 2017.

[5] P. Susanto, "Pengaruh Kualitas Pelayanan Akademik dan Citra Merek Lembaga terhadap Kepuasan Mahasiswa Universitas Negeri Padang", vol. 8, Tingkap , pp. 65-78. 2012.

[6] H. Tawas, L. Mananeke, F.F.R. Tuerah, "Analisis Kualitas Layanan Akademik dan Administrasi terhadap Kepuasan Mahasiswa", vol. 3 , Jurnal Riset Ekonomi, Manajemen, Bisnis Dan Akuntansi, pp. 422-432. 2015

[7] Y.N.A. Yeung, W.K. Chow, S.T. Law, "Survey on indoor air quality in an academic services department", vol. 37, Architectural Science Review, pp. 73-79. 1994.

[8] P.T. Balwant, K. Birdi, U. Stephan, A. Topakas, P.T. Balwant, K. Birdi, U. Stephan, A. Topakas, "Transformational instructor-leadership and academic performance: a moderated mediation model of student engagement and structural distance", vol. 9486, Journal of Further and Higher Education, pp. 1-17. 2018

[9] A. Parasuraman, V.A. Zeithaml, L.L. Berry, "A Conceptual Model of Service Quality and Its Implications for Future Research", vol. 49, Journal of Marketing, pp. 41. 1985.

[10] R. Startup, Student satisfaction with academic services, vol. 14, Educational Research, pp. 135-140. 1972

[11] P. Kotler, "Marketing strategi, employee involvement in marketing and the position of business schools", vol. 29, Marketing Strategi, Employee Involvement in Marketing and the Position of Business Schools, 1991.

[12] D.R. Aulianto, A. Alamsyah, Y. Rohmiyati, "Pengaruh Penerapan Sistem Informasi Akademik Terhadap Kualitas Layanan Akademik Mahasiswa Di Fakultas Ilmu Sosial Dan Ilmu Politik Universitas Diponegoro", vol. 1, Jurnal Ilmu Perpustakaan, pp. 1-8. 2012.

[13] A. Sufiyyah, "Pengaruh Kualitas Layanan Akademik dan Birokras terhadap Kepuasan Mahasiswa", vol. 13, Jurnal Ilmiah Aset, pp. 85-93. 2011.

[14] S.W. Hati, "Pengaruh Kepemimpinan Dan Kinerja Dosen Terhadap Mutu Pelayanan Di Politeknik Negeri Batam", vol. 9, Iqtishoduna, pp. 176. 2013 
[15] R. Hariri, "Pengaruh Perilaku Kepemimpinan Terhadap Kinerja Layanan Akademik Pegawai Di Universitas Pendidikan Indonesia”, vol. 10, Manajerial, pp. 32-41. 2011.

[16] J.R. Lehtinen, "Two approaches to service quality dimensions", vol. 11, The Service Industries Journal, pp. 287-303. 1991.

[17] N. Qotrun, S. Wibowo, "Pengukuran Kualitas Layanan Sistem Informasi Akademik", vol. 1, Jurnal Informatika Upgris (JIU), pp. 122-131. 2015.

[18] M. Joseph, B. Joseph, "Service quality in education: a student", vol. 5, Quality Assurance in Education, pp. 15-21. 2010.

[19] R. Gumilar, E. Prihatin, "Kualitas Pelayanan Administrasi Akademik D Sekolah Tinggi Ilmu Ekonomi (Stie) Se-Kota Bandung", vol. 17, Administrasi Pendidikan, pp. 115-126. 2013.
[20] M. Zineldin, S. Philipson, "Kotler and Borden are not dead: Myth of relationship marketing and truth of the 4Ps", vol. 24, Journal of Consumer Marketing, pp. 229-241. 2007.

[21] Y.H. Hung, M.L. Huang, K.S. Chen, "Total Quality Management \& Business Excellence Service quality evaluation by service quality performance matrix Service quality evaluation by service quality", vol. 14, Quality, pp. 37-41. 2010.

[22] K. Kiran, "Service quality and customer satisfaction in academic libraries", vol. 59, Library Review, pp. 261-273. 2010.

[23] B.M. Oldfield, S. Baron, "Student perceptions of service quality in a UK university business and management faculty", vol. 8, Quality Assurance in Education, pp. 85-95. 2000. 